\title{
Carl Ritter von Ghega - 2018 Surveyor of the Year
}

\author{
Rinaldo PAAR \\ University of Zagreb, Faculty of Geodesy, Kačićeva 26, 10000 Zagreb, Croatia \\ rinaldo.paar@geof.unizg.hr
}

Abstract: Carl Ritter von Ghega was proclaimed 2018 Surveyor of the Year on 21 March 2018. In this paper, we explore how this Austrian of Albanian extraction, born in Venice, played an important role in geodesy and the surveying profession and the honours he got up to the present day. We investigate his background and details of his professional path, education and most important contributions in the areas of surveying and engineering at large. We describe his most significant achievement, that is, the Semmering Railway, which was dismissed at the time as impossible to achieve. In 1998, the Semmering Railway was inscribed in the UNESCO World Heritage List. Apart from this project, which left a great impression on the engineering profession, von Ghega also developed the Borovnica Viaduct built in the mid-19th century in Slovenia.

Keywords: Carl Ritter von Ghega, European Surveyor, Semmering Railway

\section{Introduction}

Since 2012, the Council of European Geodetic Surveyors has proclaimed each year a European Surveyor of the Year. In order, these have been: Gerardus Mercator (2012), Galileo Galilei (2013), Friedrich Georg Wilhelm von Struve (2014), Euclid (2015), Ruđer Josip Bošković (2016), Guillaume-Henri Dufour (2017), and Carl Ritter von Ghega (2018). The most recent, Carl Ritter von Ghega, was proclaimed Surveyor of the Year at the inaugural Global Surveyors' Day held on 21 March 2018 in Washington DC (USA) (Figure 1). The Council organised this event with the American $\mathrm{Na}-$ tional Society of Professional Surveyors, under the auspices of the International Federation of Surveyors.

Carl Ritter von Ghega was proclaimed 2018 Surveyor of the Year by Dietrich Kollenprat (Austria) and Julian Ismaili (Albania). They also presented a poster (Figure 2). The ceremony was also attended by Maurice Barbieri (CEGS President), Jean-Yves Pirlot (CEGS General Director), Nicolas Smith (CEGS VicePresident), Vladimir Krupa (CEGS Vice-President), James Kavanagh, and Chryssy Potisou (FIG President).

Carl Ritter von Ghega was an engineer known for designing and engineering the Semmering Railway from Gloggnitz to Mürzzuschlag in Austria. He was the most prominent engineer of the mid- $19^{\text {th }}$ century (The Architect 1870). In recognition of his exceptional services, the Austrian Emperor Franz Jozef knighted him on 22 June 1851. Thus, he became Carl Ritter (Knight) von Ghega. He is numbered among the top hundred famous Austrians as the most esteemed engineer of those times (Canaj 2007).

On 11 December 2018, the Croatian Chamber of Chartered Surveying Engineers held a lecture on the person and work of Carl Ritter von Ghega to mark the occasion of his proclamation as 2018 Surveyor of the Year.

\section{Biography and Origin}

Carl Ritter von Ghega (Karl Gega in Albanian) was an Austrian of Albanian heritage. He was born on 10 January 1802 in Venice, then part of the Habsburg Monarchy. Some manuscripts give his date of birth as 13 June 1802, but this was in fact the date of his baptism. In those days, baptisms were recorded more accurately than births. He died on 14 March 1860 in Vienna in the Austrian Empire. He was buried in the central civic cemetery in Vienna alongside eminent Austrians such as Mozart, Beethoven, Schubert, Strauss, Brahms, Maria Theresa, Franz Josef, Franz Kafka, and many others (Figure 3).

KiG No. 32, Vol. 18, 2019, https://doi.org/10.32909/kg.18.32.5 - 


\title{
Carl Ritter von Ghega - geodet godine 2018.
}

\author{
Rinaldo PAAR \\ Geodetski fakultet Sveučilišta u Zagrebu, Kačićeva 26, 10000 Zagreb \\ rinaldo.paar@geof.unizg.hr
}

Sažetak: Carl Ritter von Ghega 21. ožujka 2018. proglašen je geodetom godine 2018. U ovome se radu elaborira čime je Austrijanac albanskih korijena, rođen u Veneciji, zadužio geodete i geodetsku struku te prema tome koje su mu sve počasti do danas dodijeljene. Istražuje se njegovo porijeklo te detaljno njegov profesionalni put, obrazovanje i najznačajniji doprinosi u području geodezije i inženjerstva uopće. Opisuje se njegovo najznačajnije postignuće - tzv. projekt Semerinške željeznice za koji se u to vrijeme vjerovalo da ga nije moguće realizirati. Semerinška je željeznica 1998. uvrštena na UNESCO-ov popis mjesta svjetske baštine. Osim projekta Semerinške željeznice kojim je zadužio inženjersku struku, elaborira se i vijadukt Borovnica koji je sagrađen sredinom 19. stoljeća u dolini Borovnica u Sloveniji.

Ključne riječi: Carl Ritter von Ghega, europski geodet, Semerinška željeznica

\section{Uvod}

Od 2012. godine Vijeće europskih geodeta - CLGE (fra. The Comité de Liaison des Géomètres Européens) svake godine proglašava europskog geodeta godine. Do 2019. godine redom su bili izabrani: Gerardus Mercator za 2012., Galileo Galilei za 2013., Friedrich Georg Wilhelm von Struve za 2014., Euclide za 2015., Ruđer Josip Bošković za 2016., Guillaume-Henri Dufour za 2017. i Carl Ritter von Ghega za 2018. Carl Ritter von Ghega proglašen je geodetom godine za 2018. na 1. svjetskom danu geodeta održanom 21. ožujka 2018. u Washingtonu DC, SAD (slika 1). Kako je proglašenje svečano obavljeno na 1. svjetskom danu geodeta, Carla Rittera von Ghegu može se smatrati svjetskim geodetom godine za 2018. Taj je događaj organizirao CLGE zajedno s Američkim nacionalnim društvom profesionalnih geodeta - NSPS (National Society of Professional Surveyors) pod pokroviteljstvom Međunarodne udruge geodeta - FIG (International Federation of Surveyors).

Čin proglašenja Carla Rittera von Ghege geodetom godine 2018. obavili su Dietrich Kollenprat iz Austrije i Julian Ismaili iz Albanije te su ujedno predstavili poster Carl Ritter von Ghege (slika 2). Ceremoniji proglašenja uz njih su još prisustvovali $i$ Maurice Barbieri (predsjednik CLGE-a), Jean-Yves Pirlot (generalni direktor CLGE-a), Nicolas Smith (potpredsjednik CLGE-a), Vladimir Krupa (potpredsjednik CLGE-a), James Kavanagh i Chryssy Potisou (predsjednica FIG-a).

Carl Ritter von Ghega je po zanimanju bio inženjer poznat po projektiranju i inženjeringu Semerinške željeznice od Gloggnitza do Mürzzuschlaga. Bio je najistaknutiji inženjer sredinom 19. stoljeća (The Arhitect 1870). Kao znak zahvalnosti za njegove izvanredne zasluge Austrijskom Carstvu, car Franjo Josip 22. lipnja 1851. godine proglasio ga je vitezom. Dobio je titulu vitez (njem. Ritter) te postaje Carl Ritter von Ghega. Uvršten je među 100 najslavnijih osoba u austrijskoj povijesti jer je slovio za najcjenjenijeg inženjera tadašnjeg vremena (Canaj 2007).

U Hrvatskoj je 11. prosinca 2018., u organizaciji Hrvatske komore ovlaštenih inženjera geodezije HKOIG, prigodnim pozvanim predavanjem o liku i djelu Carla Rittera von Ghege obilježeno njegovo proglašenje geodetom godine 2018.

\section{Biografski podatci i porijeklo}

Carl Ritter von Ghega (alb. Karl Gega) bio je Austrijanac albanskih korijena. Rođen je 10. siječnja 1802. u Veneciji, tadašnjoj Habsburškoj Monarhiji. U nekim se zapisima kao datum rođenja navodi 13. 


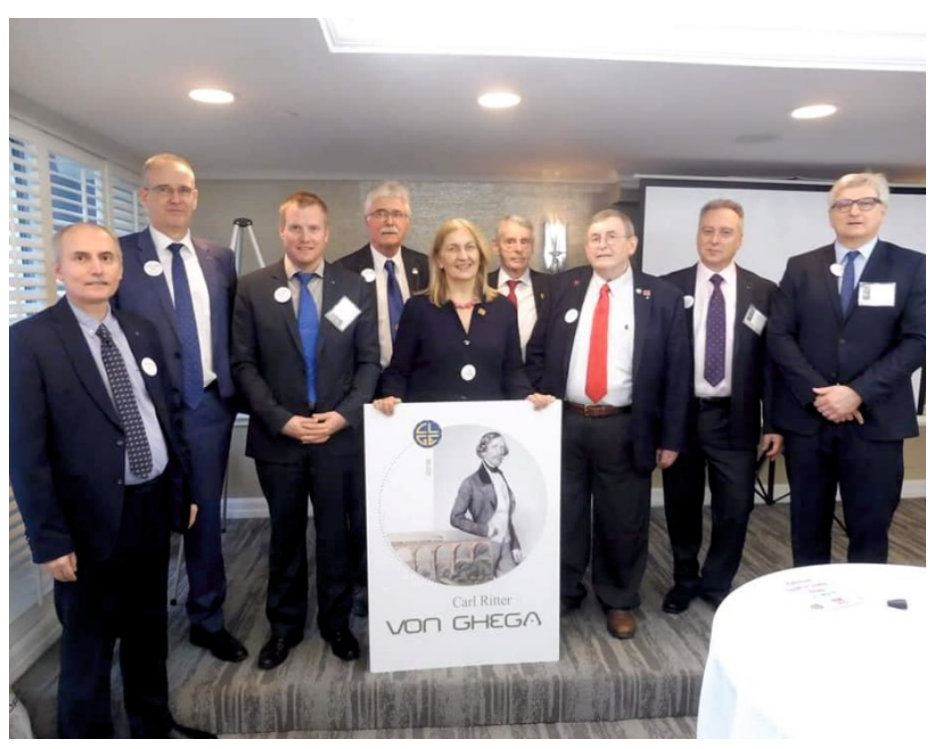

Fig. 1 Proclamation of Surveyor of the Year 2018 (FIG 2019).

Slika 1. Proglašenje geodeta godine za 2018. (FIG 2019).

At the time, rumours circulated about his tragic end, reportedly suicide due to the axes of one of the Semmering tunnels which had failed to join up correctly. However, the rumours were unfounded. Carl Ritter von Ghega died of tuberculosis and his requiem mass was held in St. Stephen's Cathedral in Vienna.

\subsection{Origins}

Carl Ritter von Ghega was an Austrian of Albanian extraction, born in Venice (Elsie 2012). His father was Anton Gega, a captain in the Venetian navy. His mother was Anna, nee Pribis. On 24 June 2005, a symposium entitled Carl Gega - Between Legend and Reality was organised by the Albanian Embassy in Vienna. It was demonstrated that Carl Ritter von Ghega was of Albanian extraction.

Ghega's ancestors emigrated from Albania to Perast in Montenegro, and from there to Venice. Gjergi Gega was a captain and judge who moved from Albania to Perast. His son, Cristofor, travelled from Perast to Venice, where he became a naval officer. Cristofor Gega (Carl's great-grandfather), had a son, Gasper (Carl's grandfather), who also became a naval officer and captain. Gasper Gega married Laura Iavelli, whose family had run the 'Albanian School' for decades in Venice. They had three children: Anton, Giovananton, and Angele. The eldest, Antonio (Anton) became a captain in the Venetian Navy and was the father of Carl. Carl Ritter von Ghega's family tree is shown in Figure 4.

\section{Education, Further Training and Career}

Carl Ritter von Ghega attended the Military School in Venice (TU Graz 2019). From 1817 to 1819 he studied mathematics and engineering at the Faculty of Engineering Sciences and Mathematics of the University of Padua, where he also attended courses in architecture at the Accademia di Belle Arti. It is recorded that he was enrolled in the second year of studies in 1818. He gained his doctorate in the field of mathematics on 11 June 1819 at the age of 17 (Stefa and Ismaili 2018).

For forty years, he served the Austro-Hungarian monarchy, and dedicated 17 years of his life to service in Venice. He spent a great deal of time engaged in professional training in order to hone his knowledge, skills and experience for the great challenges which were to face him later in life. From 1836 to 1842, he travelled around England and other European countries, studying their railway systems. In April 1842, the Austrian Empire sent him to North America to gain knowledge and experience which would stand him in good stead regarding the future project to build the Semmering Railway. While there, he investigated 39 railways which covered 2413 kilometres of track altogether (UNESCO 1998).

Upon his return to Austria, he began his professional career, primarily in the construction of railway lines.

\subsection{Professional career}

Before his work on designing, engineering and constructing railways, he began his professional engineering career in Venice, in road and hydro-technical designs. He participated in the construction of the road from Cortina d'Ampezzo to Toblach.

From 1836 to 1840 , he supervised the construction of the railway line from Brno to Breclav, also known as the Emperor Ferdinand Northern Railway, from Vienna to Krakow. In 1842, he was entrusted with the design of the future Austrian rail network. In 1844, he presented his plans for a railway from Gloggnitz to Mürzzuschlag via Semmering, known as the Semmering Railway, crossing the Semmering Pass, which until then had been considered impossible.

\subsection{Most important achievements}

Dozens of road systems, buildings and railway lines throughout the Austro-Hungarian Monarchy (in Austria, the Czech Republic, Hungary, Slovakia, Slovenia and Italy) were the result of Carl Ritter von Ghega's work.

KiG No. 32, Vol. 18, 2019, https://doi.org/10.32909/kg.18.32.5 - - 


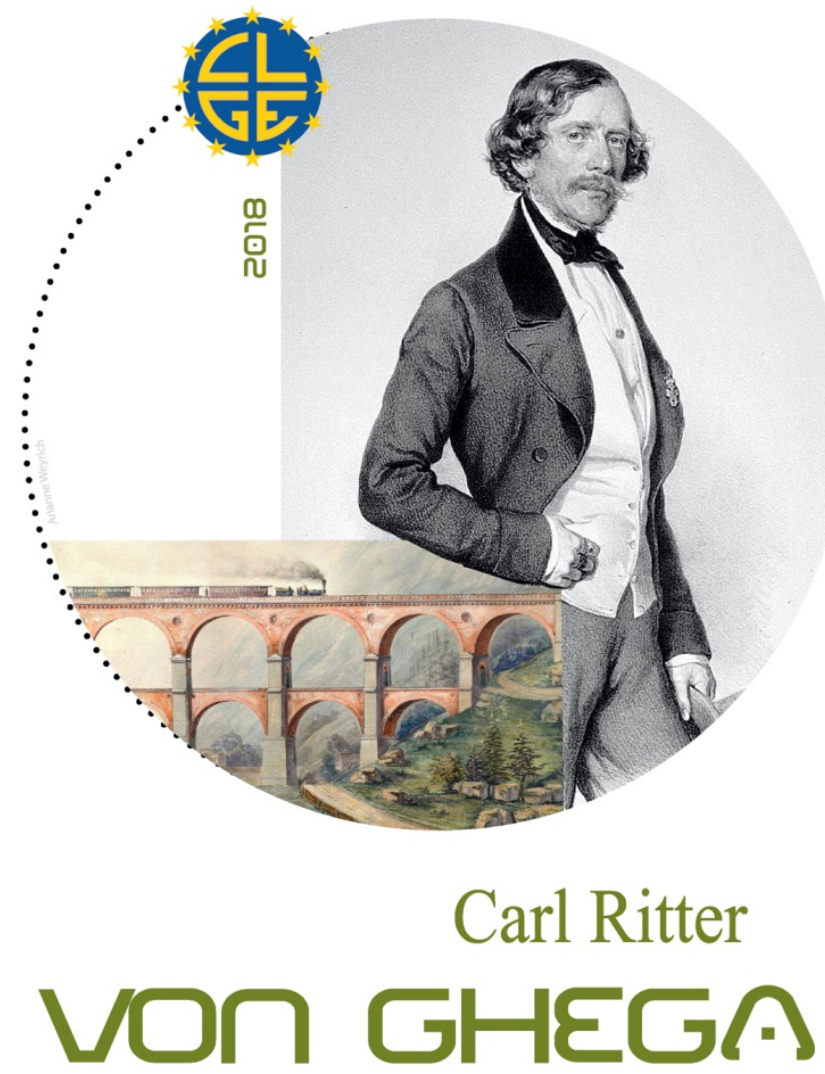

Slika 2. Poster europskog geodeta za 2018. godinu (CLGE 2019).

Fig. 2 Poster of the 2018 European Surveyor of the Year (CLGE 2019).

lipnja 1802. To je datum njegova krštenja, a s obzirom na to da se u 19. stoljeću datum krštenja smatrao važnijim od datuma rođenja, u nekim zapisima pronalazimo taj datum kao datum njegova rođenja. Umro je 14. ožujka 1860. u Beču, tadašnjem Austrijskom Carstvu. Pokopan je na gradskom groblju u Beču uz austrijske velikane poput Mozarta, Beethovena, Schuberta, Straussa, Brahmsa, Marije Tereziju, Franju Josipa, Kafku i mnoge druge (slika 3).

Svojevremeno su kružile glasine o njegovu tragičnom kraju, navodno počinjenom suicidu, zbog osi jednog od semerinških tunela koje se nisu spojile. No te glasine nisu bile istinite. Carl Ritter von Ghega umro je od posljedica tuberkuloze, a misa zadušnica održana je u bečkoj glavnoj katedrali sv. Stjepana.

\subsection{Porijeklo}

Carl Ritter von Ghega bio je Austrijanac albanskih korijena rođen u Veneciji (Elsie 2012). Otac

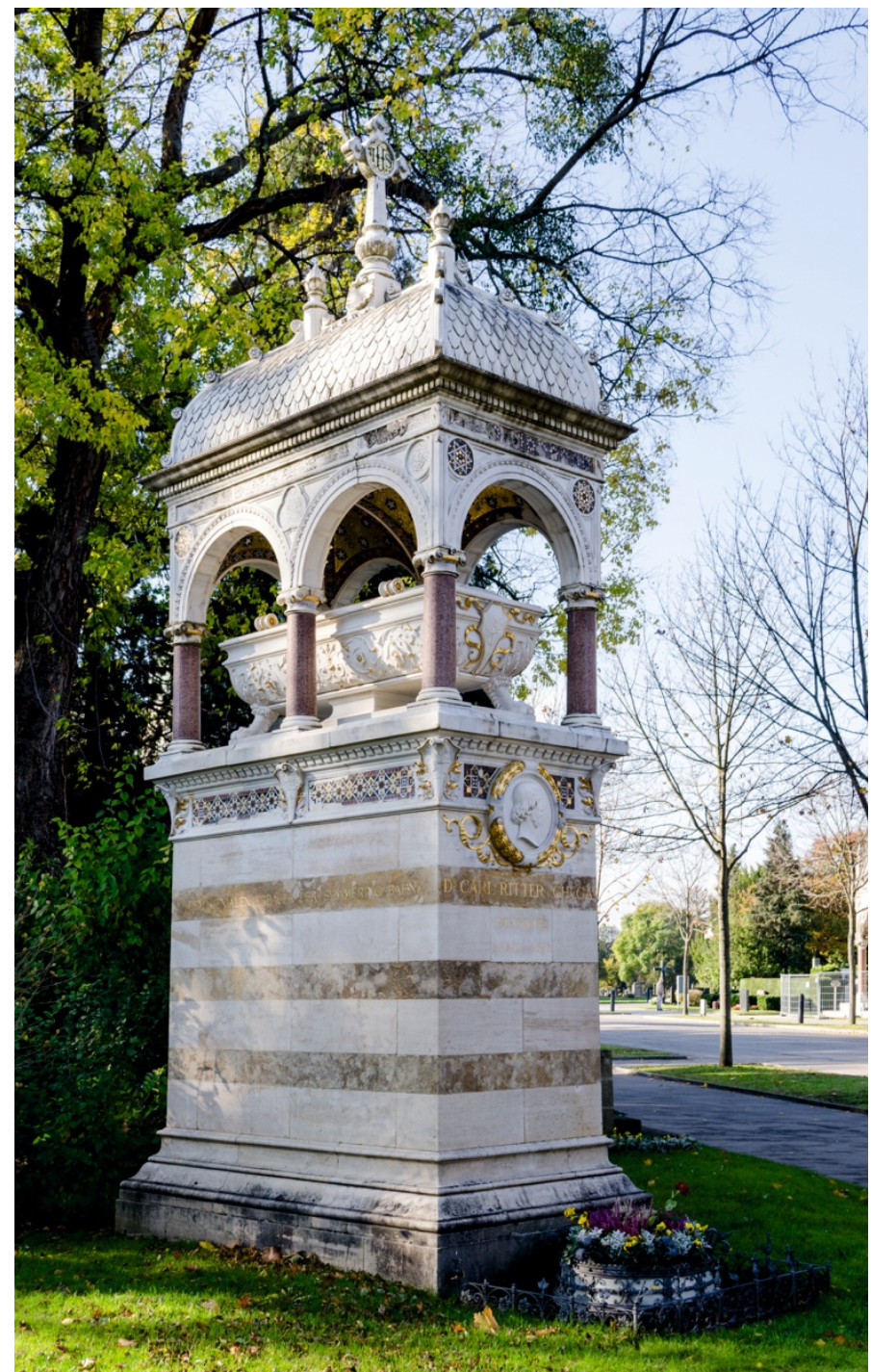

Slika 3. Grobnica Carla Rittera von Ghege na gradskom groblju u Beču (Wikipedia 2019a).

Fig. 3 Grave of Carl Ritter von Ghega in the civic cemetery in Vienna (Wikipedia 2019a).

Carla Rittera von Ghege bio je Anton Gega, kapetan venecijanske mornarice. Njegova se majka zvala Anna, rođena Pribis. Dana 24. lipnja 2005. organiziran je simpozij „Karl Gega - između legende i stvarnosti" u organizaciji Albanske ambasade $u$ Beču. Tamo je dokazano da je Carl Ritter von Ghega imao albanske korijene.

Ghegini preci emigrirali su iz Albanije $u$ Perast $u$ Crnoj Gori, a iz Perasta u Veneciju. Gjergj Gega bio je kapetan i sudac koji je došao u Perast iz Albanije. Njegov sin Cristofor bio je pomorski oficir u Veneciji u koju je otišao iz Perasta. Cristofor Gega (Carlov pradjed) imao je sina Gaspera (Carlov djed), također pomorskog oficira i kapetana. Gasper Gega oženio 


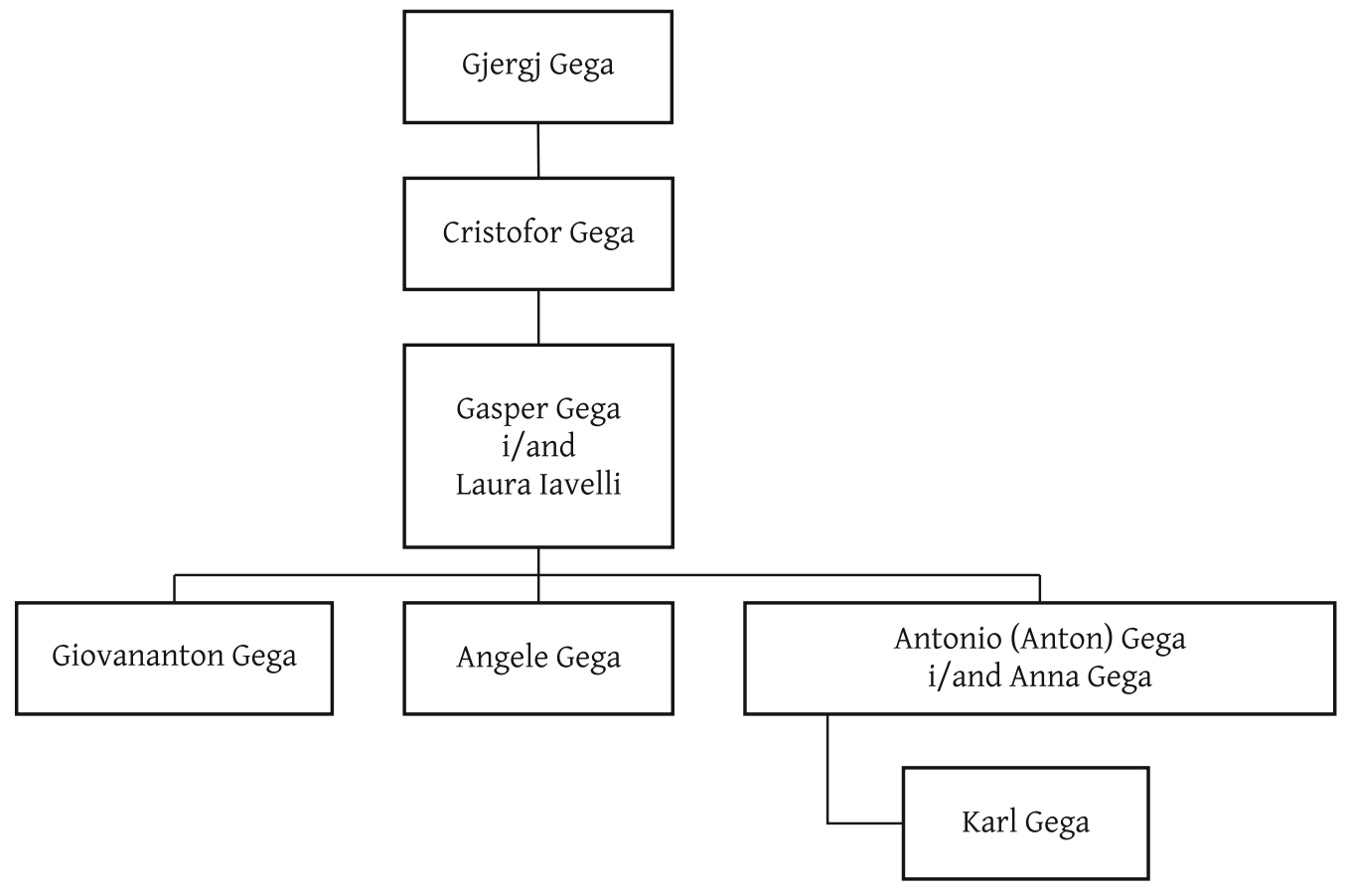

Fig. 4 Family tree of Karl Gega (Carl Ritter von Ghega).

Slika 4. Obiteljsko stablo Karla Gege (Carl Ritter von Ghega).

The following are of particular significance:

- 1820 - he designed the Venice-Tyrol road

- 1824 - he participated in the construction of the court building in Treviso on the Piazza del Duomo

- 1836-1840 - he supervised the construction of the Brno-Breclav railway

- 1839 - he designed the railway from Vienna to Brno via Ravensburg (total length: $140 \mathrm{~km}$ )

- 1840 - he designed the railway from Tyrol to Voralberg

- 1842-1847 - he designed the Semmering Railway

- 1845 - he planned the railway from Ljubljana to Trieste

- 1848-1854 - the Semmering Railway was built

- 1856 - the Borovnica Viaduct in Slovenia was built according to Ghega's plans, as part of the Austrian Southern Railway from Vienna to Trieste

- 1853 - he was appointed Head of Planning for the entire Austrian Imperial Railway network

- His last task was to build the railway in Transylvania, but he did not complete it due to his premature death.

\subsection{Accolades}

After his death, Carl Ritter von Ghega was given many honours and awards. Several streets, squares,

68 schools and museums were named after him. A series of postage stamps bearing his portrait were issued to commemmorate the Semmering Railway. In 1967, his face appeared on the Austrian 20-schilling banknote.

He was also awarded a number of titles. To the Austrians, he was known as (Stefa and Ismaili 2018):

- Imperial Ministerial Advisor

- Commandant of the Order of Franz Jozef

- Knight of the Order of the Iron Crown, 3rd class

- Knight of the Order of Leopold

- Honorary Citizen of Brno and Trieste

- Commandant of the Tuscan Order of Joseph

Only a few years after his death, his fame began to grow and spread throughout the world. Perhaps the greatest honour he received was that of the Society of Austrian Engineers and Architects to mark the $15^{\text {th }}$ anniversary of the Semmering Railway. In honour of his life and work, a large monument was erected to him at the Semmering railway station (Figure 5) and unveiled on 22 June 1869.

\section{The Semmering Railway (Semmeringbahn)}

Carl Ritter van Ghega's most significant achievement was of course the design and construction of the Semmering Railway. There had been a railway line from Vienna to Trieste since the mid- $19^{\text {th }}$ century. The section between Gloggnitz and Mürzzuschlag, KiG No. 32, Vol. 18, 2019, https://doi.org/10.32909/kg.18.32.5 - - 
je Lauru Iavelli čija je obitelj desetljećima vodila "Scuola dei Albanesi" (Albansku školu) u Veneciji. Gasper Gega i Laura Iavelli imali su troje djece: Antona, Giovanantona i Angela. Antonio (Anton) Gega, kapetan venecijanske mornarice, bio je otac Carl Rittera von Ghege odnosno Karla Gege (Canaj 2007). Obiteljsko stablo Carla Rittera von Ghege prikazano je na slici 4.

\section{Obrazovanje, profesionalno usavršavanje $i$ karijera}

Carl Ritter von Ghega najprije je pohađao vojnu školu u Veneciji (TU Graz 2019). Od 1817. do 1819. studirao je matematiku i inženjerstvo na Fakultetu filozofskih znanosti i matematike Sveučilišta u Padovi, a pohađao je i tečajeve arhitekture na Accademia di Belle Arti. Postoje zapisi da je 1818. bio registriran na drugoj godini studija. Doktorirao je iz područja matematike 11. lipnja 1819. sa 17 godina (Stefa i Ismaili 2018).

Četrdeset godina radio je u službi Austro-Ugarske Monarhije, a 17 godina u službi u Veneciji. Veliki dio svoga života posvetio je stručnom usavršavanju kako bi stekao znanja, vještine i iskustvo za svoje najveće životne izazove. Tako se od 1836. do 1842. usavršavao u Engleskoj i ostalim europskim zemljama proučavajući željeznice. U travnju 1842. poslan je na usavršavanje u Sjevernu Ameriku kako bi stekao znanja i iskustva za projekt izgradnje Semerinške željeznice. Tamo je proučavao 39 željezničkih pruga ukupne duljine 2413 km (UNESCO 1998).

Povratkom u Austriju započeo je svoj profesionalni put, primarno na izgradnji željezničkih pruga.

\subsection{Profesionalna karijera}

Prije rada na projektiranju, inženjeringu i izgradnji željezničkih pruga, svoju je profesionalnu inženjersku karijeru započeo u Veneciji projektiranjem cesta i hidrotehničkih objekata. Sudjelovao je $u$ izgradnji ceste od Cortine d'Ampezzo do Toblacha.

Od 1836. do 1840. nadgledao je izgradnju željezničke pruge od Brna do Břeclava, tzv. Emperor Ferdinand Northern Railway, i od Beča do Krakowa. Projektiranje buduće državne željezničke mreže Austrije povjereno mu je 1842., a 1844. predstavio je plan željezničke pruge od Gloggnitza preko Semmeringa do Mürzzuschlaga, poznatiju kao Semerinšku željezničku prugu kod koje je trebalo savladati Semerinški planinski prolaz za što se tada vjerovalo da nije moguće.

\subsection{Najznačajnija postignuća}

Deseci prometnica, zgrada i željezničkih pruga u Austro-Ugarskoj Monarhiji (Austrija, Češka Republika, Mađarska, Slovačka, Slovenija i Italija) rezultat su rada Carla Rittera von Ghege, a među njima izdvajamo:

- 1820. projektirao je cestu Venecija - Tyrol

- 1824. sudjelovao je u izgradnji zgrade suda u Trevisu na Piazza del Duomo

- 1836.-1840. nadgledao je izgradnju željezničke pruge Brno-Břeclav

- 1839. projektirao je željezničku prugu od Beča preko Revensburga do Brna, ukupne duljine $140 \mathrm{~km}$

- 1840. projektirao je željezničku prugu od Tirola do Voralberga

- 1842.-1847. projektirao je Semerinšku željeznicu

- 1845. planirao je željezničku prugu Ljubljana-Trst

- 1848.-1854. izgrađena je Semerinška željeznica

- 1856. izgrađen je vijadukt Borovnica u Sloveniji prema planovima Ghege kao dio austrijske Južne željeznice od Beča do Trsta

- 1853. određen je za glavnoga šefa planiranja za cijelu željezničku mrežu Austrijskog Carstva

- Povjerena mu je izgradnja željezničke pruge u Transilvaniji, no zadatak nije ostvario zbog preuranjene smrti.

\subsection{Počasti}

Nakon smrti Carl Ritter von Ghega dobio je niz raznih počasti i priznanja. Po njemu je nazvan niz ulica, trgova, škola i muzeja. S njegovim je likom izašlo nekoliko serija poštanskih maraka kojima se obilježavala Semerinška željeznica. Njegova je slika 1967. godine bila stavljena na austrijsku novčanicu od 20 šilinga.

Dodijeljen mu je i niz raznih titula. Za Austrijance on je bio (Stefa i Ismaili 2018):

- carski ministarski savjetnik

- zapovjednik reda Franje Josipa

- vitez reda željezne krune III. razreda

- vitez reda Leopolda

- počasni građanin Brna i Trsta

- zapovjednik toskanskog reda Josipa.

Samo nekoliko godina nakon smrti legenda o njemu počela je rasti i širiti se svijetom. Možda i najveće priznanje koje je dobio dodijelilo mu je Društvo austrijskih inženjera i arhitekata prilikom obilježavanja 15. godišnjice Semerinške željeznice. U spomen na lik i djelo Carla Ritter von Ghege izgrađen je i 22. lipnja 1869. predstavljen monumentalni spomenik na Semerinškoj stanici (slika 5). 


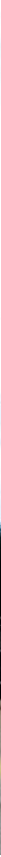

Fig. 5 Monument to Carl Ritter von Ghega at the Semmering railway station (Wikimedia Commons 2019).

Slika 5. Spomenik Carlu Ritteru von Ghegi na Semerinškoj stanici (Wikimedia Commons 2019).

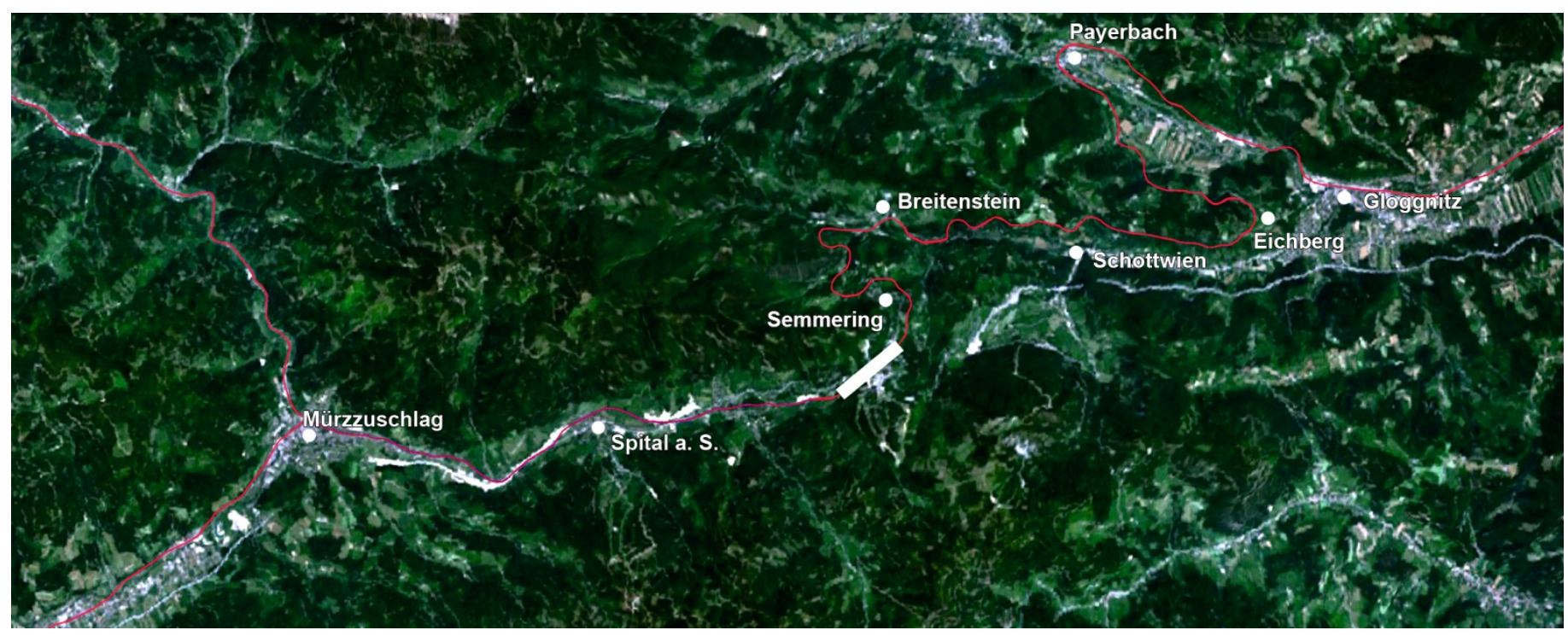

Fig. 6 Satellite image of the Semmering Railway (Wikipedia 2019d).

Slika 6. Satelitski snimak Semerinške željeznice (Wikipedia 2019d).

however, remained unfinished (Figure 6). Carl Ritter von Ghega came up with a design to connect the entire span of the railway. At the time, it was considered an impossible undertaking.

The railway line from Gloggnitz to Mürzzuschlag, via Semmering, was the first mountain railway line in Europe with a standard gauge (New World Encyclopedia 2019), and was constructed between 1848 and 1854 . The terrain was particularly challenging, and the large differences in elevation presented a definite engineering challenge in those days. It was considered particularly important to preserve the landscape and make the railway line fit into its surroundings, and this was achieved mostly due to Ghega, who ensured that passengers would enjoy an attractive railway journey with many picturesque KiG No. 32, Vol. 18, 2019, https://doi.org/10.32909/kg.18.32.5 - - - 


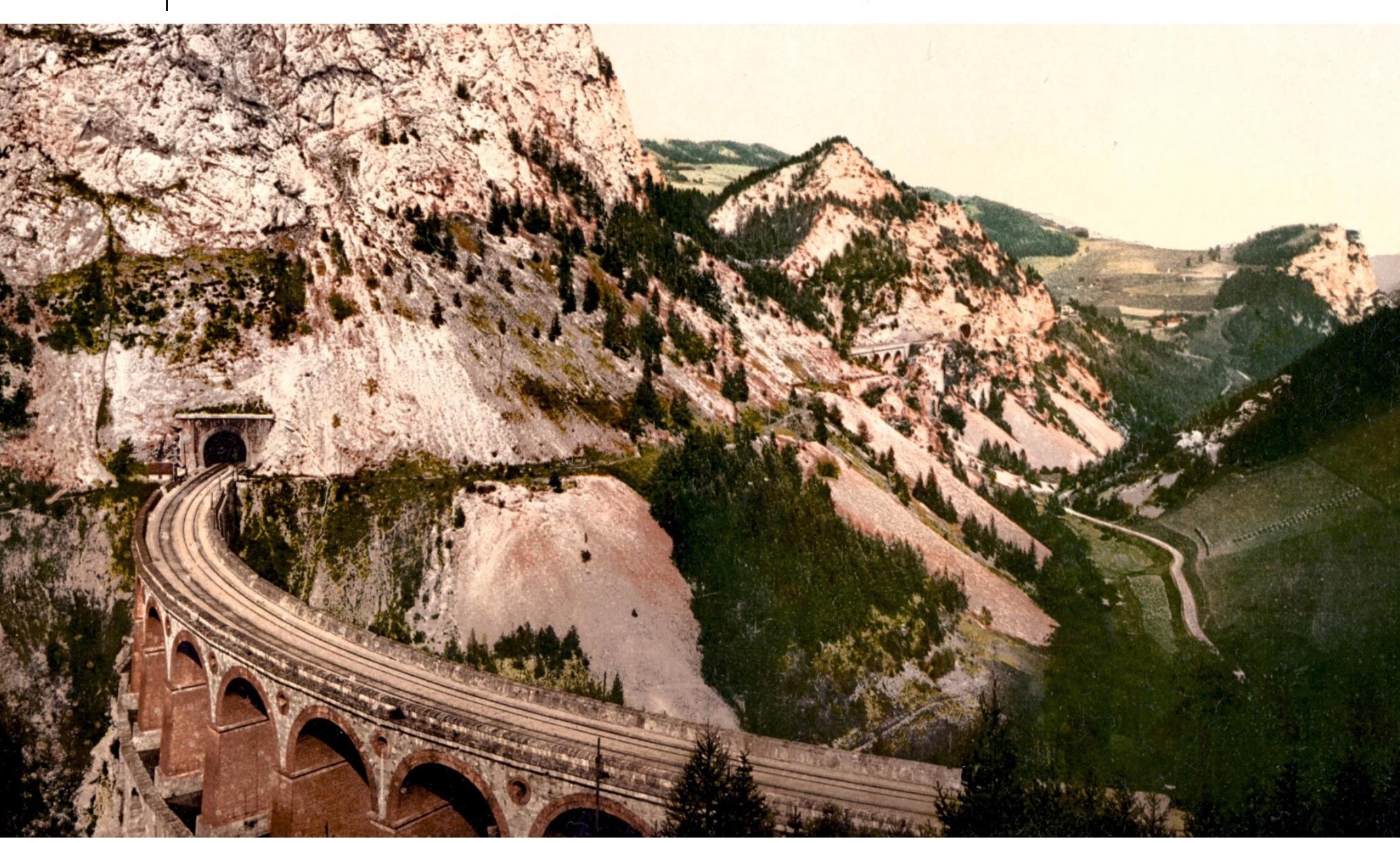

Slika 7. Vijadukt Kalte-Rinne oko 1900. godine (Wikipedia 2019d).

Fig. 7. Kalte-Rinne Viaduct, around 1900 (Wikipedia 2019d).

\section{Semmeringbahn - Semerinška željeznica}

Najznačajnije postignuće Carla Rittera von Ghege svakako je izrada projekta i izgradnja Semerinške željeznice. Željeznička pruga Beč - Trst postojala je već $\mathrm{i}$ prije sredine 19. stoljeća. Između Gloggnitza i Mürzzuschlaga protezala se praznina (slika 6). Carl Ritter von Ghega izradio je projekt za spajanje cijele željezničke pruge. $\mathrm{U}$ to se doba vjerovalo da to nije moguće.

Željeznička pruga od Gloggnitza preko Semmeringa do Mürzzuschlaga u Austriji bila je prva planinska pruga u Europi sa standardnim rasponom tračnica (New World Encyclopedia 2019), izgrađena u razdoblju od 1848. do 1854. Iznimno težak teren i velike visinske razlike bile su veliki izazov inženjerima toga doba. Očuvanje krajolika i uklapanje u okoliš bilo je od iznimne važnosti i dijelom skrbi graditelja, što je dovelo do iznimno privlačnog putovanja željeznicom koja je nudila živopisne slikovite poglede iz vlaka (slika 7). Željeznička pruga i danas je još uvijek u funkciji i dio je austrijske južne pruge Austrijskih federalnih željeznica. Putovanje vlakom 150 godina starom prugom prema alpskim zimovalištima velika je turistička atrakcija. Poznata je po prekrasnom okolišu, vilama i hotelima koji su sagrađeni između Gloggnitza i malog trgovačkog grada Schottwiena. To je područje postalo jedan od prvih alpskih odmarališta za bečku aristokraciju.

\subsection{UNESCO-vo mjesto svjetske baštine}

Semerinška je željeznica 2. prosinca 1998. na Konvenciji o svjetskoj baštini u Kyotu u Japanu uvrštena na UNESCO-ov popis mjesta svjetske baštine (UNESCO 2019). Sukladno kategorijama koje propisuje UNESCO, Semerinška željeznica je kulturni krajolik (UNESCO 1995).

Prema procjeni ICOMOS-a (International Council on Monuments and Sites) teško je utvrditi autentičnost željezničke pruge koja se konstantno koristi, održava i modernizira od 1854. godine. No autentičnost željezničke pruge-trase i izvanrednih željezničkih i 


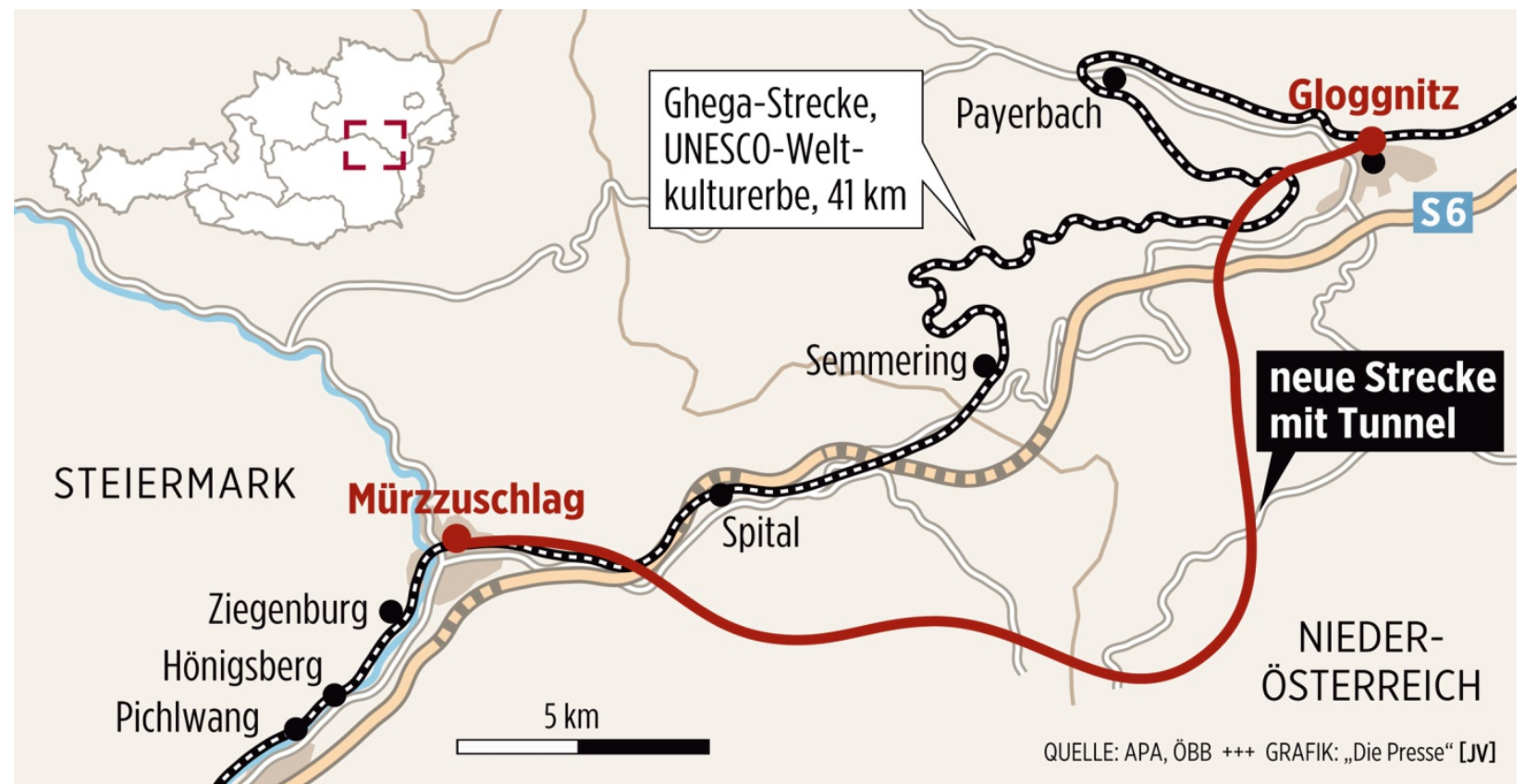

Slika 8. Trasa Semerinškog tunela (Semmering railway 2019).

Fig. 8 Semmering Tunnel (Semmering Railway 2019).

scenes from the windows their carriages (Figure 7). The railway line is still operating today as part of the Austrian Federal Railways Southern Network. Travelling by train along this 150-year-old line to Alpine winter resorts remains a huge tourist attraction. It is famous for its wonderful scenery and the villas and hotels built between Gloggnitz and the small market town of Schottwien. The area became one of the first Alpine resorts for the Vienna aristocracy.

\subsection{A place in the UNESCO World Heritage}

On 2 December 1998, the Semmering Railway was inscribed in the UNESCO List of World Heritage Sites, during the Convention on World Heritage held in Kyoto (UNESCO 2019). According to the UNESCO categories, the Semmering Railway represents a cultural landscape entity.

According to the evaluation of UNESCO experts (International Council on Monuments and Sites), it was difficult to establish the origins of the railway which had been used constantly, maintained and modernised since 1854. However, the authenticity of the railway and appertaining objects was indisputable. In addition, the influence of the railway on the landscape and environment were deemed absolutely authentic. The same conclusion in terms of the cultural landscape was reached regarding the construction of luxury villas and hotels in the late $19^{\text {th }}$ and early $20^{\text {th }}$ centuries, forming one of the first Alpine resorts for the Viennese aristocracy. The way they were carefully integrated into the Alpine landscape has been maintained up to the present day.

In May 1995, an ICOMOS expert commission visited the Semmering Railway and confirmed the above claims. However, the commission then requested a more detailed evaluation in order to review the legislation of the Republic of Austria regarding the cultural landscape in Lower Austria and Styria, including the protection of the Semmering Railway area.

The following conclusion and proposal were submitted (UNESCO 1998):

The Semmering Railway, constructed between 1848 and 1854 over $41 \mathrm{~km}$ of high mountains, is one of the greatest feats of civil engineering during the pioneering phase of railway building. Set against a spectacular mountain landscape, the railway line remains in use today thanks to the quality of its tunnels, viaducts, and other works, and has led to the construction of many recreational buildings along its tracks. It is proposed to inscribe the Semmering Railway in the World Heritage List on the basis of criteria II and IV:

- Criterion II: The Semmering Railway represents an outstanding technological solution to a major physical problem in the construction of early railways.

- Criterion IV: With the construction of the Semmering Railway, areas of great natural beauty became more easily accessible and as a result these were developed for residential as well recreational use, creating a new form of landscape.

KiG No. 32, Vol. 18, 2019, https://doi.org/10.32909/kg.18.32.5 - 


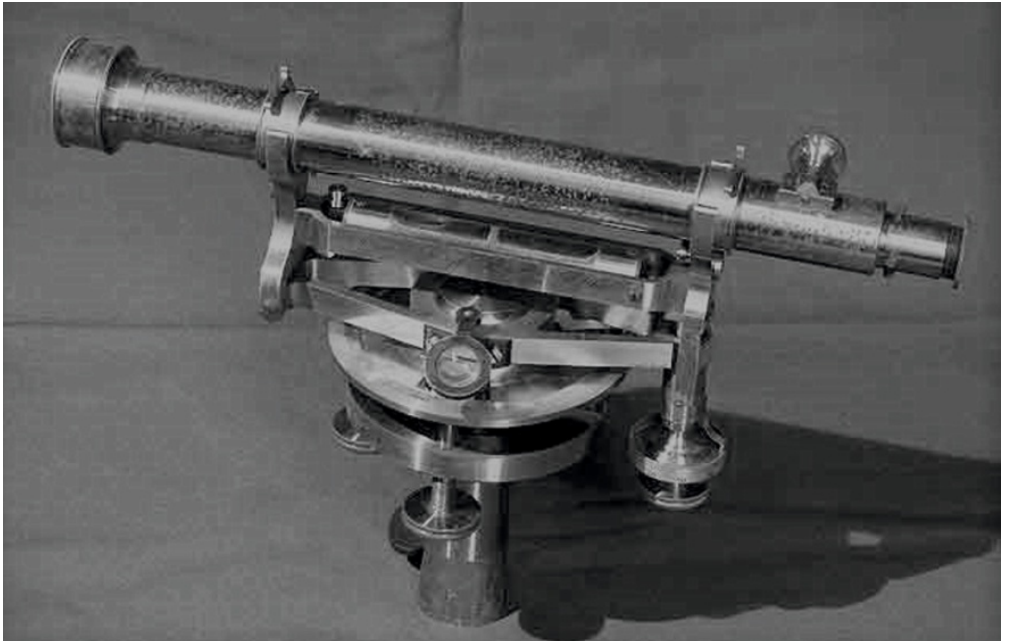

Fig. 9 Stampfer's levelling screw

(Simon von Stampfer 2019).

Slika 9. Stampferov nivelir (Simon von Stampfer 2019). pratećih objekata oko nje neupitna je. Nadalje, sveukupni utjecaj željezničke pruge na krajolik i okoliš smatra se autentičnim. Isto se može zaključiti i za kulturni krajolik napravljen krajem 19. i početkom 20. stoljeća u vidu izgradnje luksuznih vila i hotela koji su činili jedan od prvih alpskih mjesta za odmore za bečku aristokraciju. Njihovo je uklapanje u grubi alpski krajolik zadržalo svoj integritet do danas.

Stručnjaci ICOMOS-a posjetili su Semerinšku željeznicu u svibnju 1995. i potvrdili spomenute navode. Nakon toga su zatražili još detaljniju procjenu kako bi proučili zakonsku regulativu Republike Austrije vezanu za zaštitu kulturnog krajolika u Donjoj Austriji i Štajerskoj, odnosno zaštitu područja Semerinške željeznice.

Konačno je donesen sljedeći zaključak i prijedlog (UNESCO 1998):

Semerinška željeznica izgrađena je između 1848. i 1854. ukupne duljine $41 \mathrm{~km}$ u visokim planinama te je jedan od najvećih uspjeha gradevinarstva tijekom pionirske faze izgradnje željeznica. Kvaliteta njezinih tunela, vijadukata $i$ ostalih gradevinskih objekata osigurala je njezino kontinuirano korištenje do današnjeg dana, na pozadini spektakularnog planinskog krajolika, koji sadrži mnogo atraktivnih građevina za rekreaciju koje su sagrađene zbog pojave željeznicke pruge. Predlaže se da se Semerinška željeznica uvrsti na popis mjesta svjetske baštine na temeljuj kriterija II i IV:

- Kriterij II: Semerinška željeznica je izvanredno tehnološko rješenje za veliki problem u građevinarstvu tijekom pionirske faze izgradnje željeznica.

- Kriterij IV: Izgradnjom Semerinške željeznice, područja velikih prirodnih ljepota postala su dostupnija te su se razvila za rezidencijalnu i rekreacijsku upotrebu, stvarajući novi oblik kulturnoga krajolika.

Zaključak i prijedlog prihvaćeni su na Konvenciji o svjetskoj baštini u Kyotu 2. prosinca 1998. pa je Semerinška željeznica uvrštena na popis mjesta svjetske baštine.

— KiG Br. 32, Vol. 18, 2019, https://doi.org/10.32909/kg.18.32.5
S obzirom na važnost Semerinške željeznice 25. travnja 2012. započela je izgradnja Semerinškog tunela duljine $27,3 \mathrm{~km}$. Tunelom će se zamijeniti Semerinški prijelaz dugačak $41 \mathrm{~km}$. Završetak izgradnje planira se za 2026. godinu. Ukupna vrijednost izgradnje tunela iznosi 3.1 milijardu eura. Predviđena je projektna brzina od $250 \mathrm{~km} / \mathrm{h}$. Kraćom trasom tunela $u$ odnosu na staru trasu Semerinške željeznice (slika 8) i visokom projektnom brzinom omogućit će se ušteda u vremenu od 30 minuta.

\subsection{Doprinos Carla Rittera von Ghege u geodetskom smislu}

Možda najveća nepoznanica kod Carla Rittera von Ghege je njegov doprinos geodeziji. Kako je malo dostupne literature o njegovu liku i djelu, ona se intenzivnije proučava posljednjih 20-ak godina od kada je Semerinška željeznica uvrštena na UNESCO-ov popis mjesta svjetske baštine. Sukladno tome Albancima je postalo važno dokazati njegovo porijeklo. U tome su i uspjeli. Međutim, dostupne literature o njemu kao geodetu je vrlo malo.

Za potrebe izrade projekta Semerinške željeznice nisu postojale pouzdane karte toga područja. Kako ih je bilo nužno izraditi, trebalo je napraviti detaljnu izmjeru cijeloga područja koje je bilo teško pristupačno i izrazito nepovoljno. U tu je svrhu trebalo razviti nove geodetske instrumente. Carl Ritter von Ghega je u suradnji sa Simonom Ritterom von Stampferom razvio Stampfer'sche Nivellier-Höhen- und Längenmessinstrument, instrumente za mjerenje visinskih razlika i duljina, od kojih je prvi kasnije postao izuzetno važan za geodete (UNESCO 1998). Glavna je odlika toga nivelira (slika 9) mogućnost očitanja vertikalnog kuta s preciznošću 1 " te procjene desetinke 1 ". Osim toga patentirao je i vijak za horizontiranje nivelira 


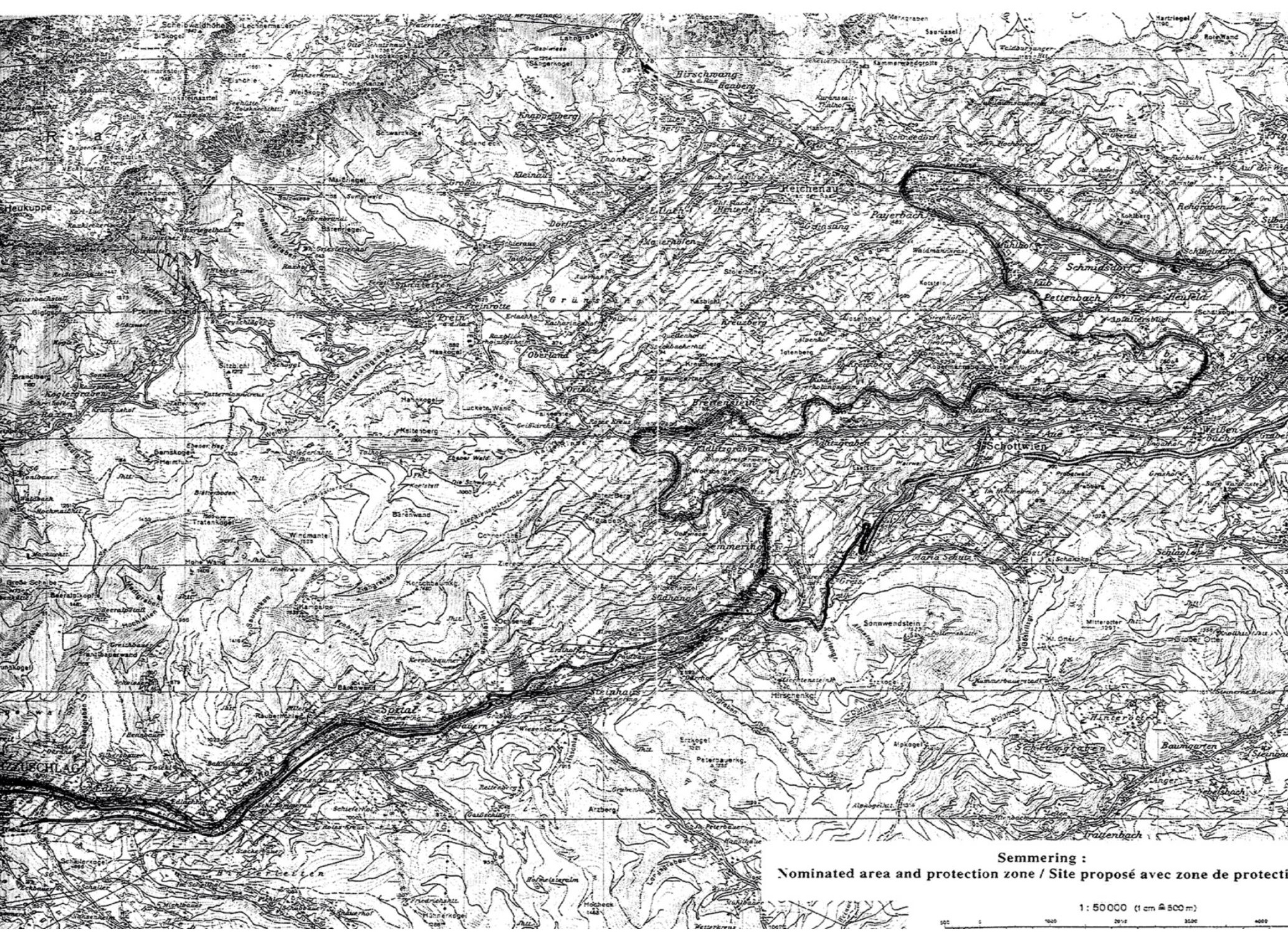

Fig. 10 Ghega's map for the projected Semmering Railway (UNESCO 1998).

Slika 10. Ghegina karta za izradu projekta Semerinške željeznice (UNESCO 1998).

The conclusion and proposal were accepted at the World Heritage Convention held in Kyoto on 2 December 1998, and the Semmering Railway was inscribed in the World Heritage List.

Regarding the importance of Semmering railway the construction of the $27.3 \mathrm{~km}$ long Semmering Tunnel began on 25 April 2012. It has been designed to replace the $41 \mathrm{~km}$ Semmering Pass crossing. It is envisaged that construction will be completed by 2026 . The total cost of the tunnel will be around 3.1 billion euros, and the projected speed of the locomotives will be up to $250 \mathrm{~km} / \mathrm{h}$. The shorter length of the tunnel compared to the old Semmering Railway track (Figure 8) and the high speed projected will create a time saving of around 30 minutes.

\subsection{Carl Ritter van Ghega's contribution to surveying}

Carl Ritter von Ghega's contribution to surveying is perhaps the least known aspect of his work. Since there is little literature available regarding his life and work, it has only been researched more thoroughly in the last 20 or so years since the Semmering Railway was inscribed in the World Heritage List. In accordance with this, Albania invested efforts to prove his heritage. They have succeeded. However, the literature about von Ghega as a surveyor is limited.

There were no reliable maps of the area available when the Semmering Railway was designed. Since good maps were necessary, a detailed survey of the KiG No. 32, Vol. 18, 2019, https://doi.org/10.32909/kg.18.32.5 - - 


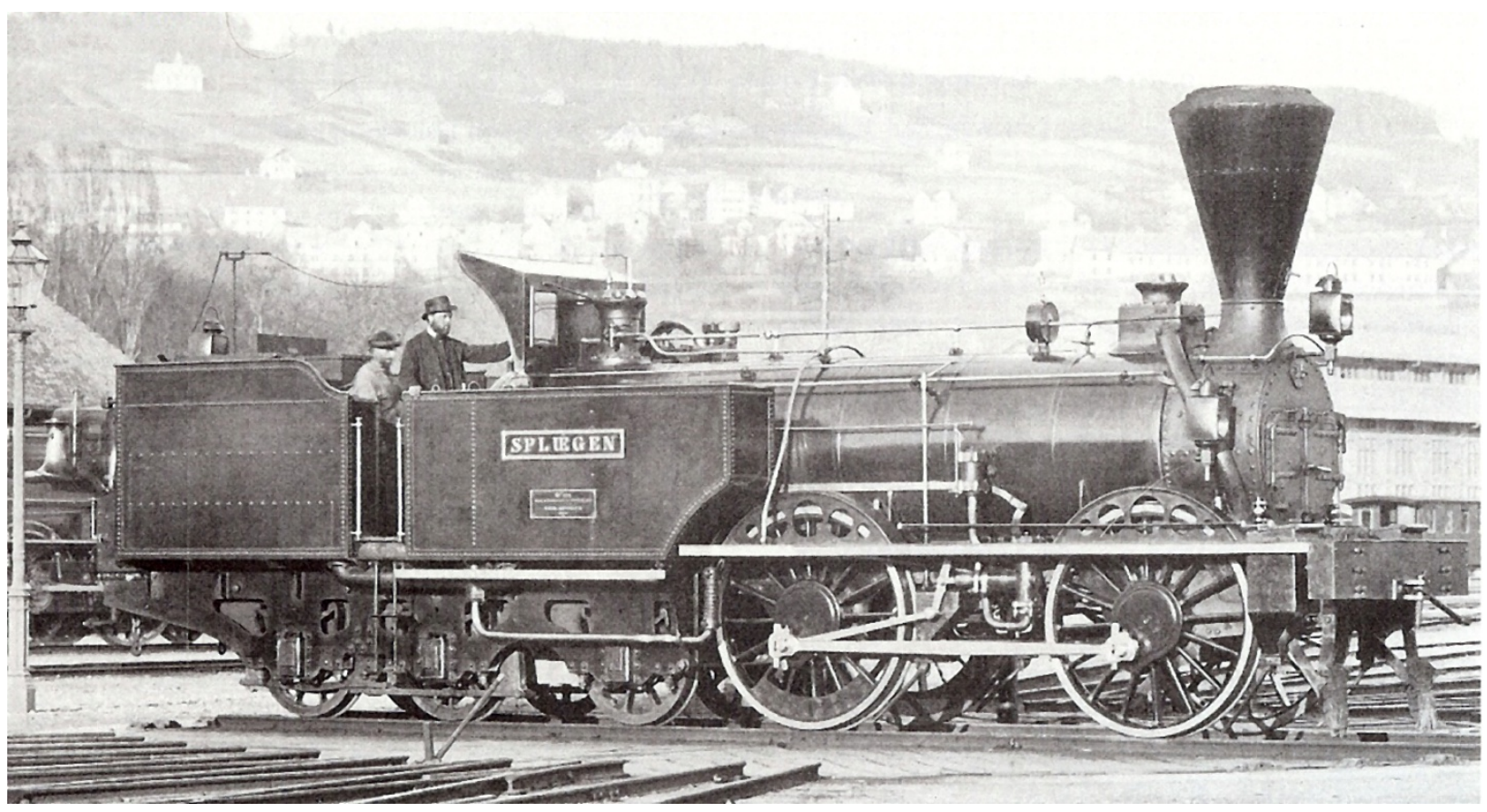

Slika 11. Engertova lokomotiva (Wikipedia 2019c).

Fig. 11 Engerth's locomotive (Wikipedia 2019c).

(Allmer 1996, Simon von Stampfer 2019). Pomoću tih instrumenata napravio je kartu cijeloga područja od Gloggnitza do Mürzzuschlaga (slika 10) koja je poslužila za izradu projekta Semerinške željeznice.

Nakon izrade projekta trebalo ga je prenijeti na teren. Prema dostupnoj literaturi već je 1831. godine Ghega razvio instrument za iskolčenje kružnih krivina (Allgemeine Bauzeitung 1836, The planimetrica collection 2019) koji se kasnije koristio za iskolčenje projekta Semerinške željeznice.

\subsection{Tehnički podatci}

Glavni inženjer Semerinške pruge bio je Carl Ritter von Ghega, koji ju je projektirao između 1842. i 1847. godine. Pruga je građena od 1848. do 1854. godine. Gradnju je započelo 1007 muškaraca i 414 žena, a sveukupno do kraja gradnje je sudjelovalo oko 20 000 radnika. Nažalost, $u$ to doba sigurnosne mjere nisu bile na visokoj razini tako da je za vrijeme gradnje poginulo oko 1000 radnika. Cijela željeznička trasa sastoji se od 14 tunela ukupne duljine $1477 \mathrm{~m}, 16$ vijadukata, nekoliko višekatnih, ukupne duljine 1477 $\mathrm{m}$, od kojih je najdulji $328 \mathrm{~m}$. Izgrađeno je i $118 \mathrm{ka}-$ menih mostova, te 11 manjih željeznih mostova. Ukupna duljina željezničke trase od Gloggnitza preko Semmeringa do Mürzzuschlaga iznosi $41 \mathrm{~km}$, a visinska razlika je $459 \mathrm{~m}$. Dozvoljeni maksimalni nagib iznosi $40 \mathrm{~mm} / \mathrm{m}$, minimalni radijus kružnih krivina
190 m, maksimalni radijus kružnih krivina 285 m, a projektirana brzina je $11,5 \mathrm{~km} / \mathrm{h}$.

Izgradnja se, neovisno o svim izazovima, odvijala po planu te je završena na vrijeme. Željeznička je pruga prvi puta puštena u promet 17. srpnja 1854. Odmah su se prevozili i putnici i roba. Veliki je izazov bila i izrada novih modela lokomotiva koje će biti u stanju savladati takve, za ono doba velike nagibe. Četiri su se tvrtke (Bavaria, Neustadt, Seraing, Vindobona) prijavile na natječaj za izradu lokomotiva, no, iako su sve četiri zadovoljile uvjete natječaja, nijedna nije pobijedila. Nisu se smatrale ni pogodnima ni pouzdanima za serijsku proizvodnju (Wikipedia 2019b). Wilhelmu von Engerthu povjereno je da od dostavljenih rješenja na natječaj od svakoga uzme ono najbolje te njihovom kombinacijom nađe novo rješenje (Hamilton 1968). Rezultat je bio iznimno uspješan u vidu novodizajnirane Engerthove lokomotive (slika 11) pa je željeznička pruga puštena u promet na vrijeme (UNESCO 1998). Između 1853. i 1854. konstruirano je ukupno 16 lokomotiva koje su ostvarivale prosječnu brzinu od $19 \mathrm{~km} / \mathrm{h}$, znatno višu od definirane projektne brzine od $11,5 \mathrm{~km} / \mathrm{h}$.

Semerinška je željeznica kroz povijest doživjela mnogo promjena i sanacija upotrebom novih i modernijih materijala poput betonskih blokova. Te su promjene bile potrebne iz više razloga, kao npr. radi povećanja opterećenja na osovinama vagona s 13 t na 22,5 t koje imamo danas. Nadalje, značajan je 
entire region, including its inaccessible and difficult parts, had to be carried out. For this purpose, new surveying instruments were deemed necessary. In cooperation with Simon Ritter von Stampfer, Carl Ritter von Ghega developed the Stampfer'sche Nivellier-Höhen- und Längenmessinstrument for measuring elevation and distance differences. The former were to become exceptionally important for surveyors (UNESCO 1998). The main feature of the levelling instrument (Figure 9) was the ability to read the vertical angle to a precision of 1 ", assessing the tenth of 1 ". Also, a screw for horizontal levelling was patented (Allmer 1996, Simon von Stampfer 2019). Using these instruments, a map of the entire area from Gloggnitz to Mürzzuschlag (Figure 10) was created and used for the Semmering Railway project.

The project design and production needed to be applied in the field. In the literature, we find that as early as 1831, Ghega developed an instrument for staking out curvature (Allgemeine Bauzeitung 1836, The Planimetrica Collection 2019), which was later used to stake out the Semmering Railway project.

\subsection{Technical data}

The chief designer/engineer of the Semmering Railway was Carl Ritter von Ghega. He made this project from 1848 till 1847, while the railway was built from 1848 till 1854. The construction begun with 1007 men and 414 women, and until the end there were around 20000 workers involved in the construction. Unfortunately, in those times security measures were very low so more than 1000 workers died during the construction. Semmering Railway consists of 14 tunnels long $1477 \mathrm{~m}, 16$ viaducts, a few more storey tunnels long $1477 \mathrm{~m}$, and the longest is $328 \mathrm{~m}$. 118 stone bridges and 11 smaller iron bridges were also built. Total length of the Semmering Railway from Gloggnitz over Semmeringato to Mürzzuschlag is $41 \mathrm{~km}$, elevation difference is $459 \mathrm{~m}$. Allowed maximum incline is $40 \mathrm{~mm} / \mathrm{m}$, minimum curve radius $190 \mathrm{~m}$, maximum curve radius $285 \mathrm{~m}$, and design project speed is $11.5 \mathrm{~km} / \mathrm{h}$.

In spite of the challenges, construction proceeded according to plan and was completed on time. The railway line was officially launched on 17 July 1854. It was used immediately for passenger and freight transport. A major challenge was the production of new locomotives which could cope with the steep incline, which at the time was considered immense. Four companies (Bavaria, Neustadt, Seraing and Vindobona) competed for production, but none

76 was accepted, although all four met the tender requirements. They were not considered suitable or reliable for serial production (Wikipedia 2019b). Wilhelm von Engerth was given the task of selecting the best elements from each of the tenders and charged with producing a combined solution (Hamilton 1968). The result was the exceptionally successful, newly-designed Engerth locomotive (Figure 11) and the railway was launched on time (UNESCO 1998). Between 1853 and 1854, 16 locomotives were built with an average speed of $19 \mathrm{~km} / \mathrm{h}$, which was significantly higher than the planned speed of $11.5 \mathrm{~km} / \mathrm{h}$.

The Semmering Railway underwent many changes and repairs over the years, and new, modern materials such as cement blocks were incorporated. These changes were necessary for several reasons, for example, increasing wagon axle loads from $13 \mathrm{t}$ to $22.5 \mathrm{t}$, which are still used today. Great progress was achieved when journey speeds were increased thanks to the development of new locomotives and the upgrading of the railway upper structure. Major changes occurred between 1957 and 1959 when the entire railway was electrified. It has been maintained continuously since 1854. All the railways and appertaining objects are owned by the Austrian state railways.

\section{Borovnica Viaduct}

Apart from the Semmering Railway project and constructions, a series of other projects was important (see section 3.2), but in this section, we will describe the construction of the Borovnica Viaduct in more detail (Figure 12). The viaduct was built in the Borovnica Valley in Slovenia between 1850 and 1856. It was part of the Austrian Southern Railway from Vienna to Trieste. It was famous for being the largest stone bridge of its time in Europe. A million cubic metres of stone rubble were used to build it, along with five million bricks and a million cubic metres of stone blocks.

The chief designer and engineer for Borovnica Viaduct was Carl Ritter von Ghega. The length of the viaduct was $561 \mathrm{~m}$ and the maximum height was over the ground $38 \mathrm{~m}$. The lower part of the viaduct consisted of 22 arches, and the upper part of the viaduct consisted of 25 arches. The materials used were bricks and rubble stone. The bridge was erected on wooden oak piles sunk into the shallow marshland.

Before the outbreak of the Second World War, the condition of the viaduct was already poor. For decades, it had been washed by water and the brickwork had deteriorated, while the oak piles supporting it had begun to disintegrate and the entire structure

KiG No. 32, Vol. 18, 2019, https://doi.org/10.32909/kg.18.32.5 - - 


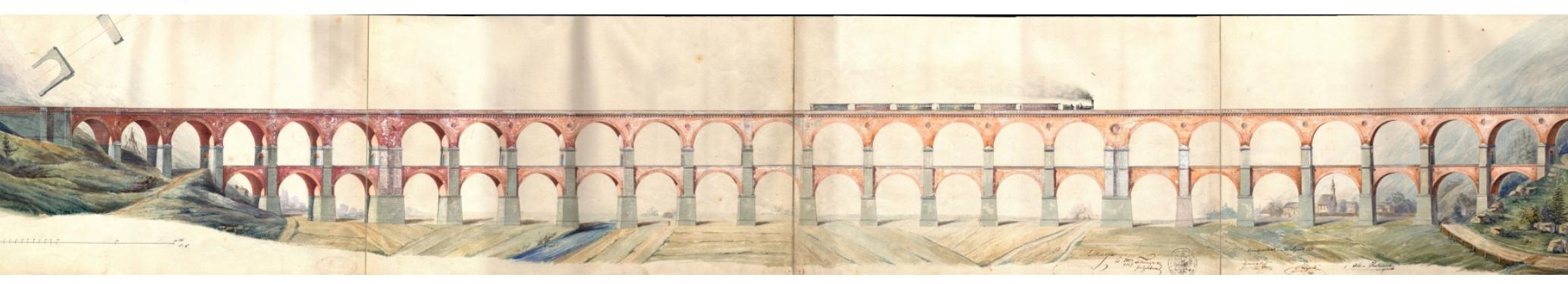

Fig. 12 Borovnica Viaduct - original plans (Wikipedia 2019e).

Slika 12. Vijadukt Borovnica - originalni plan (Wikipedia 2019e).

napredak postignut u povećanju brzine vožnje razvojem novih lokomotiva i unapređenjem gornjeg ustroja željezničke pruge. Najveća je promjena napravljena od 1957. do 1959. kada je cijela željeznička pruga elektrificirana. Održavanje traje kontinuirano od 1854. Željeznička pruga i svi objekti koji su s njom povezani u vlasništvu su Austrijskih državnih željeznica.

\section{Vijadukt Borovnica}

Osim projekta i izgradnje Semerinške željeznice izdvaja se još niz raznih drugih projekata (vidi poglavlje 3.2), a u ovome se poglavlju detaljnije prikazuje izgradnja vijadukta Borovnica (slika 12). Vijadukt je izgrađen $u$ dolini Borovnica $u$ Sloveniji $u$ razdoblju od 1850. do 1856. Bio je dio austrijske Južne željeznice od Beča do Trsta. Poznat je kao najveći kameni most toga doba u Europi. Za izgradnju vijadukta utrošeno je milijun kubičnih metara lomljenog kamena, pet milijuna opeke i milijun kubičnih metara kamenih blokova.

Glavni projektant $\mathrm{i}$ inženjer izgradnje vijadukta Borovnica bio je Carl Ritter von Ghega. Duljina vijadukta iznosila je $561 \mathrm{~m}$, a maksimalna visina iznad tla $38 \mathrm{~m}$. Donji dio donjeg ustroja vijadukta sastojao se od 22 luka, a gornji dio od 25 lukova. Za materijal je upotrijebljena opeka i lomljeni kamen, a cijeli je vijadukt postavljen na drvenim pilotima od hrasta koji su bili uronjeni u plitko močvarno područje.

Prije početka Drugog svjetskog rata vijadukt je bio u lošem stanju. Voda je desetljećima prodirala $u$ vijadukt slabeći opeku, a hrastovi stupovi koji su ga podupirali počeli su propadati, što je rezultiralo time da se cijela građevina postupno slegla. Vlakovi koji su prolazili morali su usporiti na $5 \mathrm{~km} / \mathrm{h}$. Početkom Drugog svjetskog rata u Jugoslaviji vojska koja se povlačila razorila je dio mosta. Talijanske su snage željeznom konstrukcijom zamijenile dio vijadukta koji je nedostajao. Nakon što su se Talijani povukli, njemačke su snage izgradile obilaznicu pokraj vijadukta zbog opasnosti od sve češćih zračnih napada. Nakon posljednjeg velikog savezničkog zračnog napada 1944. godine djelomično uništeni vijadukt nije popravljen. Željeznica je 1947. godine preusmjerena na rub doline Borovnice gdje i danas prometuje. Preostali dio vijadukta postupno je demontiran do 1950. Danas je ostao samo jedan stup vijadukta usred Borovnice za uspomenu (Wikipedia 2019e).

\section{Zaključak}

Carl Ritter von Ghega, kao i mnogi stručnjaci, inženjeri i znanstvenici toga doba, bio je vrlo svestran. Studirajući matematiku i inženjerstvo, doktorirao je sa samo 17 godina iz područja matematike. Za vrijeme studija pohađao je i tečajeve arhitekture. Nakon studija počeo se baviti projektiranjem cesta, zgrada i proučavanjem željeznica. Daljnjim neprestanim usavršavanjem po cijelome svijetu stekao je znanja i vještine potrebne za izradu najsloženijih projekata željezničkih trasa onoga doba. Iznad svega se izdvaja izrada projekta i izgradnja Semerinške željeznice. Suočen s tim izazovom, shvatio je da će svoja znanja morati proširiti i na područje geodezije. Naime, uvidio je da za izradu kvalitetnog projekta nedostaju detaljne i pouzdane karte toga područja. Da bi njih izradio trebao je napraviti detaljnu izmjeru cijeloga područja buduće Semerinške željeznice. U tu je svrhu zajedno sa Simonom Ritterom von Stampferom razvio nove geodetske instrumente, preciznije i pouzdanije, kojima je bilo moguće izmjeriti cijelo područje. Desetak godina prije izrade projekta Semerinške željeznice razvio je instrumente za iskolčenje krivina. Razvoj svih tih instrumenata omogućio je izradu projekta, njegovo iskolčenje i u konačnici izgradnju Semerinške željeznice, mjesto svjetske baštine prema UNESCO-u. Upravo je izradom svih tih instrumenta i karte Semerinškog područja zadužio geodeziju koja mu je odala priznanje proglasivši ga geodetom godine 2018 . 
had gradually sunk. Trains crossing it were forced to slow down to $5 \mathrm{~km} / \mathrm{h}$. During the early months of the war, the Yugoslav army blew up part of the bridge as they retreated. The Italian forces replaced the damaged parts with an ironwork construction. After the Italians withdrew, the Germans built a road next to the viaduct to cope with increasing air attacks. After the final major Allied air strike in 1944, the partially damaged viaduct was not repaired. The railway line was rerouted in 1947 along the edge of the Borovnica valley, where it is still located today. The rest of the viaduct was demolished piece by piece in 1950. Today, only one pillar remains as a reminder of the Borovnica Viaduct (Wikipedia 2019e).

\section{Conclusion}

Like many experts, engineers and scientists of the time, Carl Ritter von Ghega was a polymath. He studied mathematics and engineering and took his doctorate at the tender age of 17 . He also took architecture courses during his studies. After completing his studies, he began to design roads and buildings and to study railways. He continued his studies around the world and gained knowledge and skills which allowed him to create extremely complex designs for the railway systems of the age in which he lived. The most important was for the Semmering Railway. Faced with its challenges, he realised that he needed to deepen his knowledge of surveying. He noticed immediately that the maps of the area were sadly lacking in the detail and reliability required for such a project. In order to produce better maps, he needed to conduct a detailed survey of the entire Semmering Railway area. To this end, he developed new surveying instruments with Simon Ritter von Stampfer which were more precise and reliable. A decade earlier, he developed instruments to stake out curves. The development of these instruments facilitated the project plans, staking out and final construction. The Semmering Railway is a UNESCO World Heritage site. Carl Ritter von Ghega's production of these instruments and his map of the Semmering area has indebted him to the science of geodesy, which paid him homage in 2018 by proclaiming him Surveyor of the Year.

\section{References / Literatura}

Allgemeine Bauzeitung (1836) Ghega's Messinstrument für Kreise, No. 41, 337-340, 345-346

Allmer F (1996) Simon von Stampfer 1790-1864. ein Lebensbild, in: Mitteilungen der geodätischen Institute der Technischen Universität Graz, Nr. 82, Graz

Canaj A (2007): Karl Gega, between legend and reality. Albanian ecellence, no. 1, Albanian centre of excellence

CLGE (2019) Documents, http://www.clge.eu/documents/posters//Ghega_2018.pdf, Accessed 26 Jan 2019

Elsie R (2012) A Biographical Dictionary of Albanian History. I. B. Tauris. p. 166

FIG (2019) News from FIG, http://www.fig.net/news/news_2018/03_GSD-photos.asp, Accessed 18 Jan 2019

New World Encyclopedia (2019) Semmering Railway, https://www.newworldencyclopedia.org/entry/Semmering_Railway\#cite_note-2, Accessed 29 Aug 2019

Semmering railway (2019) Semmering railway http://suitcaseandpassport.com.au/rail-semmering.html, Accessed 30 Aug 2019

Stampfer, S. von (2019) Privilegien, http://ww1.clubosttirol.at/stampfer/st_privilegien.htm, Accessed 30 Aug 2019

Stefa B, Ismaili J (2018) Karl Ritter Von Ghega - The world famous Engineer with Albanian origin. Presentation organized by the Association of Kosovo Surveyors held on 19 April 2018

The Architect (1870): The engineer of the Semmering railway. The Architect, Volume 3. 175 Strand W.C. 1870. p. 184.

The planimetrica collection (2019) Otto Decher ( $\left.{ }^{*} 1845 ; \dagger 1903\right)$, https://planimetrica.jimdo.com/mathematical-instruments/germanIz/decher/, Accessed 29 Aug 2019

TU Graz (2019): Carl Ritter von Ghega, http://history.tugraz.at/besonderheiten/groessen_der_technik/ghega.php, Accessed 30 Aug 2019

UNESCO (1995): Operational Guidelines for the Implementation of the World Heritage Convention

UNESCO (1998): Evaluations of cultural properties. World heritage convention, Kyoto, Japan

UNESCO (2019) UNESCO World Heritage Committee Adds 30 Sites to World Heritage List - UNESCO World Heritage Centre, https://whc.unesco.org/en/news/164/, Accessed 29 Aug 2019

Wikimedia Commons (2019) Semmering Bahnhof Ghega-Denkmal, https://commons.wikimedia.org/wiki/File:GuentherZ_2010-0717_0043_Semmering_Bahnhof_Ghega-Denkmal.jpg, Accessed 30 Aug 2019

Wikipedia (2019a) Carl Ritter von Ghega, https://en.wikipedia.org/wiki/Carl_Ritter_von_Ghega, Accessed 26 Jan 2019

Wikipedia (2019b) Semmering railway, https://en.wikipedia.org/wiki/Semmering_railway, Accessed, 29 Aug 2019

Wikipedia (2019c) Engerth locomotive, https://en.wikipedia.org/wiki/Engerth_locomotive, Accessed 30 Aug 2019

Wikipedia (2019d) Semmeringbahn, https://de.wikipedia.org/wiki/Semmeringbahn, 30 Aug 2019

Wikipedia (2019e) Borovnica Viaduct, https://en.wikipedia.org/wiki/Borovnica_Viaduct, Accessed 30 Aug 2019 